\title{
Shanghai's History Curriculum Reforms and Shifting Textbook Portrayals of Japan
}

\section{Edward Vickers and Yang Biao}

\section{(2) OpenEdition \\ 10 Journals}

Electronic version

URL: http://journals.openedition.org/chinaperspectives/6317

DOI: 10.4000/chinaperspectives.6317

ISSN: 1996-4617

\section{Publisher}

Centre d'étude français sur la Chine contemporaine

\section{Printed version}

Date of publication: 1 December 2013

Number of pages: 29

ISSN: 2070-3449

\section{Electronic reference}

Edward Vickers and Yang Biao, «Shanghai's History Curriculum Reforms and Shifting Textbook Portrayals of Japan », China Perspectives [Online], 2013/4 | 2013, Online since 01 December 2016, connection on 28 October 2019. URL : http://journals.openedition.org/chinaperspectives/6317 ; DOI : 10.4000/chinaperspectives.6317 


\title{
Shanghai's History Curriculum
}

\section{Reforms and Shifting Textbook}

\section{Portrayals of Japan}

\author{
EDWARD VICKERS AND YANG BIAO
}

\begin{abstract}
This article examines the coverage of Japan in Shanghai's senior high history textbooks since the early 1990s - a period when the city's status as China's "showpiece for the global era" has been widely touted. Uniquely among cities on the Chinese mainland, Shanghai has throughout this period enjoyed the right to publish and prescribe its own textbooks for use in local schools (a right extended to most other regions only since the early 2000s). The portrayal of Japan in local texts thus offers a window onto the way in which a self-avowedly "global" Chinese metropolis has balanced an outward-looking and internationalist vision with the requirement for history to serve patriotic education. It also sheds light on the meaning and extent of local curricular "autonomy" in contemporary China.
\end{abstract}

KEYWORDS: Shanghai, China, Japan, history, education, identity, autonomy, war, modernity.

n post-Mao China, the pursuit of national "progress" has typically trumped that of socialist equality. Just as schools and universities have, in practice if not always in name, been divided into "key" institutions and the rest, so certain cities and provinces have been assigned flagship status as China has charted a course for "modernity." Shanghai, whose international culture and capitalist heritage counted against it during the Maoist era, by the 1990s found itself in the vanguard of a renewed push for export-oriented, capitalist economic growth. This vanguard status extended to the realm of education, as in 1990 the decision was taken to designate the city as China's only "educational experimental zone." (1) If certain cities or regions were to fulfil their developmental potential, then they would have to be liberated from the old Stalinist shackles. Where Shanghai led, the rest of China might then follow - providing the results of its greater license met with Party approval. But the precise extent of that license has remained vague and uncertain.

In this article, we examine the coverage of Japan in Shanghai's senior high history textbooks since the early 1990s. This period has seen Shanghai vie with Hong Kong for the status of China's main gateway to the outside world, (2) but the city has also reflected the rising tensions between China and its main Asian trading partner. For example, the anti-Japanese demonstrations of April 2005, sparked by outrage at the Japanese government's approval of extreme right-wing history textbooks and its bid for permanent UN Security Council membership, were "particularly large and violent in that most cosmopolitan of China's cities, Shanghai, Deng Xiaoping's showpiece for the global era." (3) The portrayal of Japan in local history texts offers a window onto the tensions, within official discourse, between a vision of an outward-looking and open China and one that focuses on the legacy of "national humiliation."
Senior high texts provide the fullest exposition of the officially-authorised narrative underpinning history education at all levels of schooling. Moreover, their senior high years represent for most students their final experience of formal instruction in history. Indeed, the majority give up history after the first two years of senior high, with only those in the "arts and humanities" stream studying it for a third year. We therefore focus primarily on the texts for the first and second years. The focus on senior high texts is further warranted by the rapid expansion of access to education at this level over the period in question. In the mid-1990s, in Shanghai, as in China generally, many students abandoned their schooling before senior high level. However, by the early 2000s the growth of the university sector meant that most Shanghai students were attending senior high school and sitting the college entrance examinations (the gaokao).

This article begins with a brief discussion of the political and ideological context - both domestic and international - for Shanghai's curriculum development since the early 1990s. It discusses shifts in policy and educational scholarship that have impinged on the preparation of the history curriculum, making comparative reference to Hong Kong, Shanghai's chief rival for the status of China's premier "global city." An overview is then provided of the three textbook series used in local high schools since the early 1990s, discussing the historiographical and pedagogical assumptions that have informed them, and ways in which these are reflected in the portrayal of Japan

1. Su Zhiliang, "The 'others' in Chinese history textbooks: A focus on the relationship between China and Japan," in Gotelind Muller (ed), Designing History in East Asian Textbooks, Routledge, 2011, pp. 147-162, p. 149.

2. Ming K. Chan, "Introduction: The SAR in flux," in Ming K. Chan and Alvin Y. So (eds), Crisis and Transformation in China's Hong Kong, M.E. Sharpe, 2002, pp. 13-14.

3. Christopher Hughes, Chinese Nationalism in the Global Era, Routledge, 2006, p. 151. 
in each successive series. The article concludes by discussing how depictions of Japan in local history textbooks have changed, the possible reasons for these changes, and their implications. Among the questions addressed are: to what extent have local textbooks offered a vision of Japan distinct from that offered in mainstream official discourse (especially as manifested in textbooks and museums); and what can the changing portrayal of Japan in local history textbooks tell us about the nature and limits of Shanghai's autonomy in curricular matters?

\section{History education, politics, and ideology in contemporary China}

The Sino-Japanese relationship has been bedevilled, particularly since the end of the Cold War, by deep mistrust on both sides. Portrayals of each country in the other's school texts need to be considered against this backdrop. Chinese mistrust has been reinforced by a perception that much of Japan's political elite remains unreconciled to and unapologetic for past military aggression. The Japanese high school history curriculum is cited as evidence, with right-wing revisionist texts attracting vehement criticism from Chinese officials, media, and the wider public. However, as Yang Biao notes elsewhere, (4) Japan's school curriculum actually allots far more coverage to Chinese history than vice versa - even if China fades from the narrative in the modern period. In China, by contrast, it is in textbook coverage of the modern era that the spotlight is trained most intently on Japan. ${ }^{(5)}$

The development of history education in China since the early 1990s has been subject to two countervailing trends: on the one hand, a desire to use history as a vehicle for patriotic education; and on the other, an interest in the potential of history as a tool for fostering critical and analytical "skills." (6) Japan has been a particular focus of history-as-patriotic-education - as the chief agent of China's "humiliation" in the modern era, ${ }^{(7)}$ and hence the main foil for arousing patriotic indignation. Although officials have recently seemed concerned at the intensity of popular anti-Japan sentiment, ${ }^{(8)}$ having pinned its colours to the patriotic mast, the Party's capacity for altering course is constrained by concerns for its own legitimacy.

At the same time, many academic educationalists and policymakers have been attracted by notions, associated with the post-1960s "New History" movement in the US and Britain, that history should be regarded as a vehicle for teaching generic "skills" and for stimulating imagination and creativity. ${ }^{(9)}$ This vision was originally linked to progressive pedagogical objectives, such as nurturing attitudes and capabilities associated with the exercise of liberal-democratic citizenship. However, the vaunted rise of the "global knowledge economy" has prompted emphasis on the economic dividends to be gained from fostering analytical and creative "skills." Shanghai's position at the forefront of China's opening to the outside world, and related ambitions to engage with that "knowledge economy," appear to have rendered local policymakers and curriculum developers especially susceptible to both sets of arguments - concerning the utility of history in promoting generic thinking skills, and its role in fostering cosmopolitan tolerance and openness.

The idea that history should be used to promote "critical thinking" has long been espoused by curriculum developers in Hong Kong ${ }^{(10)}$ - Shanghai's main rival as China's "world city." Despite increasing contacts with the mainland, Hong Kong's education system remains constitutionally distinct. Nevertheless, similar tensions in the aims ascribed to history education have been evident there. Since the retrocession, there have been official efforts to promote a state-centred patriotic orthodoxy - with implications for the portrayal of Japan in local textbooks. However, irrespective of such shifts, anti-Japanese sentiment has long been a strong component of Chinese identity at the popular level. (11) Indeed, anti-Japanese sentiment relating to the War of Resistance is one thing that broadly unites rather than divides Hongkongers and mainlanders. For most Hong Kong people, the external "other" that above all defines their "Hongkongese" distinctiveness is mainland China. In this context, increasingly negative textbook portrayals of Japan appear to have been approved as one way of reminding locals of the sentimental ties that bind them to the "motherland."

Until the 1990s, Hong Kong's most popular senior high history textbooks presented a strikingly positive interpretation of Meiji-era Japan, depicting it as a model of Asian modernisation. (12) However, portrayals have since become significantly more negative. Hong Kong texts have increasingly highlighted Japan's failure honestly to confront its wartime past. The latest edition of the most widely-used history textbook singles out Japan's handling of the dispute over the Diaoyu Islands as one among a number of ways in which the country has mismanaged post-war relations with its neighbours. ${ }^{13)}$ (See also Christine Han's article in this special feature of China Perspectives.)

In the pre-1949 era, Hong Kong and Shanghai served as twin bridgeheads for overseas trade, investment, and cultural influence. In recent decades they have converged once again, economically and culturally, as a result not just of Hong Kong's retrocession but also of changes within the People's Republic. Nowhere on the contemporary mainland seems so unabashedly postsocialist as Shanghai, and nowhere is a "pre-liberation" pattern of class inequality more in evidence; indeed, as visitors to Xintiandi or the Bund area can observe, there has been a fashion in recent years for celebrating the bourgeois lifestyle and heritage of the pre-1949 metropolis. ${ }^{(14)}$ Shanghai's status as the birthplace of Chinese modernity - of a nation that is strong, proud, and internationally respected - has come to eclipse its status as the birthplace of the Chinese Communist Party. ${ }^{(15)}$ Eschewing a narrow focus

4. In a forthcoming study (in Chinese) of the changing portrayal of China in Japanese textbooks.

5. Caroline Rose, "Changing Views of the Anti-Japanese War in Chinese High School History Textbooks," in Paul Morris, Naoko Shimazu, and Edward Vickers (eds), Imagining Japan in Post-war East Asia, Routledge, 2013, pp. 129-148.

6. Alisa Jones, "Changing the Past to Serve the Present," in Edward Vickers and Alisa Jones (eds), History Education and National Identity in East Asia, Routledge 2005, pp. 65-100.

7. Suisheng Zhao, "A state-led nationalism: The patriotic education campaign in post-Tiananmen China," in Communist and Post-Communist Studies, Vol. 31, No. 3, 1998, pp. 287-302. Britain's Opium Wars are blamed for inaugurating the "century of humiliation." But it is in the face of Japanese invasion and occupation that the national crisis is typically portrayed as reaching its apogee.

8. See article by Yinan He in the current special issue.

9. Alisa Jones, "Changing the Past to Serve the Present,"op. cit. See also Li Fan, "New curriculum reform and history textbook compilation in contemporary China," in Gotelind Muller (ed), Designing History in East Asian Textbooks, op. cit., Chapter 6. Li discusses some of the contradictions inherent in attempts to promote an "open world view" and a highly nationalist account of the Chinese past.

10. Edward Vickers, In Search of an Identity: The politics of history as a school subject in Hong Kong, 1960s-2005, Hong Kong, Comparative Education Research Centre, 2005.

11. Paul Morris and Edward Vickers, "Unifying the Nation: The role of Sino-Japanese history in Hong Kong's schools," in Paul Morris, Naoko Shimazu and, Edward Vickers (eds), Imagining Japan in Postwar East Asia, op. cit.

12. Ibid. At senior secondary level in Hong Kong, History and the separate subject of Chinese History are options taken by a diminishing minority of students.

13. Ibid.

14. See Kirk Denton, "Museums, memorial sites and exhibitionary culture in the People's Republic of China," The China Quarterly: Special Issue on Culture in the Contemporary PRC, No. 183, 2005, pp. 565-586. Also Edward Vickers, "Museums and Nationalism in Contemporary China," Compare, Vol. 37, No. 3, June 2007, pp. 365-382.

15. Nowadays what matters is the Party's championing of "advanced" forces of all kinds - a view enshrined as Party orthodoxy by Shanghai's former boss, Jiang Zemin, in his "important thought" of "The Three Represents." 
Edward Vickers and Yang Biao - Shanghai's History Curriculum Reforms and Shifting Textbook Portrayals of Japan

Table 1 - Shanghai history textbook editions and their portrayal of Japan

\begin{tabular}{|c|c|c|c|c|c|}
\hline Date & Publisher & Volumes & Scope/Focus & $\begin{array}{l}\text { Ideological } \\
\text { framework }\end{array}$ & Portrayal of Japan \\
\hline 1995(iii) & $\begin{array}{l}\text { Shanghai } \\
\text { Educational } \\
\text { Press }\end{array}$ & $\begin{array}{l}\text { Two } \\
\text { volumes }\end{array}$ & $\begin{array}{l}\text { Modern } \\
\text { world history } \\
\text { (nineteenth- } \\
\text { twentieth } \\
\text { centuries) }\end{array}$ & $\begin{array}{l}\text { Marxist / } \\
\text { historical } \\
\text { materialist / } \\
\text { internationalist }\end{array}$ & $\begin{array}{l}\text { First victim but then triumphant exponent of "Western" cap- } \\
\text { italism and imperialism; influence of successful modernisation } \\
\text { on China noted; rise of fascism attributed to "feudal rem- } \\
\text { nants" and economic crisis; distinction drawn between elite } \\
\text { and masses; postwar economic miracle hailed; failure to con- } \\
\text { front "war crimes" in China and elsewhere noted. Little men- } \\
\text { tion of the impact of war on Japan's civilian population. (i) }\end{array}$ \\
\hline 2004 (iii) & $\begin{array}{l}\text { Shanghai } \\
\text { Educational } \\
\text { Press }\end{array}$ & $\begin{array}{l}\text { Two } \\
\text { volumes } \\
\text { (plus a } \\
\text { volume } \\
\text { for Year 3) }\end{array}$ & $\begin{array}{l}\text { History of world } \\
\text { civilisations } \\
\text { (ancient times } \\
\text { to present), } \\
\text { thematically } \\
\text { presented }\end{array}$ & $\begin{array}{l}\text { Liberal / } \\
\text { cosmopolitan }\end{array}$ & $\begin{array}{l}\text { Marginally discussed in the main two volumes, implicitly } \\
\text { subsumed into the category of Chinese or "Sinic" civilisation. } \\
\text { Passing references to technological modernisation, atomic } \\
\text { bombings, (ii) dangerous religious cults (Aum Shinrikyo) and } \\
\text { Japan's role in smuggling opium into China. Year } 3 \text { volume } \\
\text { (for humanities students) similar in content and approach } \\
\text { to the } 1995 \text { text. }\end{array}$ \\
\hline$\stackrel{2007}{\rightarrow}$ & $\begin{array}{l}\text { East China } \\
\text { Normal } \\
\text { University } \\
\text { Press }\end{array}$ & $\begin{array}{l}\text { Six volumes } \\
\text { (plus a } \\
\text { volume } \\
\text { for Year 3) }\end{array}$ & $\begin{array}{l}\text { History of the } \\
\text { world from } \\
\text { ancient times to } \\
\text { the present day, } \\
\text { chronologically } \\
\text { narrated }\end{array}$ & $\begin{array}{l}\text { Nation-centred, } \\
\text { with Marxist } \\
\text { veneer }\end{array}$ & $\begin{array}{l}\text { Japan's history and its aggression against China once again } \\
\text { covered in discrete chapters. Achievements of modernisation } \\
\text { hailed, but no mention of influence on China. Descent into fas- } \\
\text { cism and militarism portrayed as driven by "civil society." } \\
\text { Elite/mass distinction absent. Heightened emphasis on } \\
\text { wartime atrocities. }\end{array}$ \\
\hline
\end{tabular}

i This is similarly ignored in the subsequent two editions.

ii Mentioned in all three editions, but without discussion of impact on Nagasaki or Hiroshima, the experiences of Japanese victims, etc.

iii Dates of publication of the formally "approved" editions; "experimental" editions were in use from 1993 and 2003 respectively.

on the heroic exploits of Communist figures, and skirting themes of class struggle and capitalist exploitation, institutions such as the Shanghai Municipal History Museum and the Bund Museum celebrate the economic vibrancy of cosmopolitan "Old Shanghai," adopting a perspective similar to that seen in the Hong Kong Museum of History. ${ }^{(16)}$ These accounts of the local past do not dwell on the theme of "national humiliation" highlighted in many other Chinese museums. However, rather than clashing with official "patriotic" ideology, hailing international commercial success arguably taps another strand therein. As Kirk Denton observes, celebrations of the affluence of pre-revolutionary Shanghai, and side-lining issues of class exploitation or collaboration with foreign "oppressors," in fact support an "ideology of entrepreneurship" that is entirely consistent with the regime's overall economic strategy. ${ }^{(17)}$

An increasingly broad-church patriotism has assumed growing importance for regime legitimation since the upheavals of 1989 and subsequent collapse of the Soviet bloc. Party-sanctioned histories still rehearse the language of historical materialism, ${ }^{(18)}$ but presenting class struggle as the driving force of historical change is problematic in a society characterised by rampant capitalism. Indeed, China arguably presents an acute case of the ideological "fracture" evident elsewhere as the bipolar certainties of the post-war order have crumbled. ${ }^{(19)}$ As early as 1988, the CCTV documentary series River Elegy (He Shang) emphatically rejected state socialism, reaffirming faith in enlightenment ideals. Foreshadowing Fukuyama's 1989 End of History thesis, the programme's makers condemned the inward-looking, oppressive stagnation of post-Ming China, instead praising liberalism and openness as the sources of Western (and Japanese) strength and prosperity. 1989 itself saw the publication of a Chinese translation of Paul Kennedy's bestseller The Rise and Fall of the Great Powers, ${ }^{(20)}$ analysing the relationship between the command of economic resources and the capacity to project military power - a subject of intense interest within China, and destined to receive the full CCTV treatment in the 2006 documentary Rise of the Great Powers (Da Guo Jue Qi).

Popular and media interest in the historical dynamics of state power has intensified even while enlightenment ideals - liberal or Marxist - have lost traction since Tiananmen. In an atmosphere of "totalitarian nostalgia" during the 1990s, attempts were made to fill the resulting ideological void with alternative "holistic systems, paradigms, and arguments for the salvation of China." (21) Often these amounted to "xenophobic screeds" since, as a beleaguered group of liberal intellectuals put it in 1997, "propagating nationalism is the safest form of political opportunism there is [in China today]." (22) This neo-nationalist turn derived additional impetus from writings such as Huntington's The Clash of Civilisations?, which fuelled resentment at Western arrogance, condescension, and hostility. ${ }^{(23)}$ The interaction of domestic and international intellectual currents thus helped reinforce "a new sense of aggrieved national sentiment" that came to play "a pivotal role in pro-

16. See Edward Vickers, In Search of an Identity, op. cit., pp. 68-75.

17. Kirk Denton, "Museums, memorial sites and exhibitionary culture in the People's Republic of China," op. cit., p. 182.

18. Arif Dirlik, "Marxism and Social History," in Brian Moloughney and Peter Zarrow (eds) Transforming History, Hong Kong, Chinese University Press, 2011, pp. 375-401.

19. On America, see Daniel T. Rodgers, Age of Fracture, Harvard University Press, 2011. On China's post-revolutionary neoliberal "depoliticisation," see Wang Hui, The End of the Revolution: China and the Limits of Modernity, London, Verso, 2009.

20. Translated by Chen Jingbiao and published as Da Guo de Xing Shuai by the China Economics Press (Zhongguo jingji chubanshe).

21. Geremie Barmé, In the Red, Columbia University Press, 1999, pp. 316-317.

22. Ibid., p. 370. Among such "screeds" was The China that Can Say No (Zhongguo keyi shuo bu, 1996), taking its inspiration from The Japan that Can Say No (1989), co-authored by Tokyo's neonationalist mayor, Ishihara Shintaro.

23. Geremie Barmé, In the Red, op. cit., p. 371. 
viding political coherence and creating a framework of consensus in dealing with pressing international issues," including those involving Japan. (24)

This was the political and intellectual climate in which Shanghai embarked on the development of its own senior high school history textbooks. Mainstream narratives continued to reflect entrenched assumptions regarding progress and national subjecthood, but largely jettisoned the substance (if not the terminology) of socialism. The resulting historiographical vision had much in common with those of early twentieth-century nationalists, and of their intellectual and political heirs in post-war Hong Kong and Taiwan. In the 1990s, as in the 1900s, an obsession with measuring China's progress against Western and Japanese benchmarks was matched by resentment of those same powers for past aggression or present slights. In the rush to learn from "developed" nations, Shanghai was tasked with renewing its old role as the main bridgehead for modernisation. But in a climate of xenophobic nationalism and "totalitarian nostalgia," to what extent would local history curriculum developers prove willing or able to emphasise themes of cosmopolitan openness? And as the prime target of nationalist resentment, how would Japan fare in the textbooks of China's most liberal city?

\section{The 1995 (1993) series ${ }^{(25)}$}

Until the 1990s, all Chinese school textbooks were published by the People's Education Press (PEP) in Beijing. In 1993, a revised national curriculum for history was issued, reflecting the themes of the new patriotic education campaign. Subsequent PEP texts featured enhanced coverage of China's "humiliation" by foreign powers during the nineteenth and twentieth centuries, with a particular focus on the wars with Japan. ${ }^{(26)}$ The contrast highlighted in earlier accounts of the "War of Resistance" between Communist heroism and KMT weakness or perfidy was downplayed in favour of a narrative emphasising the united efforts of all Chinese people. Meanwhile, as Deng Xiaoping relaunched his efforts to reform and open up the Chinese economy, further autonomy was granted to "special economic zones" and "economically developed areas" - extending to some aspects of the education system. However, the only city that actually published its own history textbook series at this time was Shanghai.

It was only after national curriculum reforms in 2001-2002 that diversification of the school textbook market occurred nationally, with four publishers (including PEP) eventually coming to dominate. Analysing senior high textbook accounts of the Anti-Japanese war, Caroline Rose finds that despite significant differences, the proportion of content devoted to this topic has generally declined across all series. However, much of what has been omitted or compressed consists of accounts of the KMT-CCP struggle and discussions of military strategy. What is left effectively heightens the focus on the reasons for Japan's invasion; its brutal nature; the unity and determination of the Chinese people in their resistance to it; and China's crucial contribution to the global war against fascism. "Stripping out the details and complexities of the domestic struggle between communists and nationalists," she argues, "actually throws a harsher spotlight on the horrors of China's war with Japan." (27) The paring back of accounts of the war actually reflects the extent to which an "extreme othering" of Japan has become "a core article of faith of mainstream discourse on the national past" - as relayed through film, television, and the popular media, as well as school texts. In other words, Caroline Rose argues that textbooks no longer deluge students with detail on this topic in part because they no longer need to - they can "allude to what are now established tropes of the officially-sanctioned narrative [...], leaving students to flesh out the details from the now vast plethora of popularly-available sources." (28)

Shanghai, however, has continued to produce its own high school history textbooks, rather than buying in texts from one of the four nationally-dominant publishing houses. The first Shanghai series was published "experimentally" in 1993 before being formally "approved" in 1995. Its narrative of modern national and global history was essentially consistent with that of the PEP texts. For example, though the account of the War of Resistance emphasises the leading role of the Communist Party and ineffectual performance of the KMT in the early years of the anti-Japan struggle (up to the Xi'an Incident of late 1936), the account of "all-out war" from 1937 follows the PEP texts in according greater recognition to the contribution of KMT forces to the conventional fighting (zhengmian zhanchang). (29) Discussion of the "violence of the Japanese army in occupied areas" cites Japan's use of Pan-Asianist slogans calling for "unity between Japan, China, and Manchuria" and ronghe tixie (mutual "solidarity, guidance, and support"). The hollowness of such rhetoric is demonstrated by the Nanjing Massacre, said here to have killed "more than 200,000" and featuring atrocities such as the infamous "killing competition." ${ }^{(30)}$ The establishment of puppet governments in Nanjing and Beiping illustrates the Japanese policy of "using Chinese to govern Chinese" (yi hua zhi hua). A later section on "China after the outbreak of war in Europe" notes the perfidy of Chiang Kai-shek in trying (unsuccessfully) to negotiate a cessation of hostilities with Japan because of his desire to continue the struggle against the CCP. The text claims that the "liberated [i.e. CCP-controlled] areas became the main arena for the war of resistance." (31)

Despite such essential similarities in content and interpretation, the organisational structure of the 1995 Shanghai text was radically different not only from its PEP counterpart, but also from textbooks used in Japan, Korea, or Taiwan. Rather than dealing with "national" and "world" history separately, the Shanghai texts sought to present a more integrated account. Chinese events were discussed alongside those in other countries - for example in Chapter 2 on "China and Japan after the opening of the new trade routes" or Chapter 17 on "National democratic movements in late nineteenth and early twentieth century Asia, Africa, and Latin America." Chapters were subdivided along national lines, but repeatedly invited comparison and the drawing of connections between national histories. The only East Asian precedent for such an approach to the presentation of modern history at high school level was to be found in Hong Kong. (32)

Underlying this integrated approach was a still distinctively Marxist narrative substructure. The text begins with a chapter on "The Rise of Capitalism

24. For a nuanced analysis of filmic portrayals of the Sino-Japanese conflict, focusing on recent "arthouse" cinema, see Kinnia Yau Shuk-ting, "Meanings of the Imagined Friends: Cood Japanese in Chinese War Films," in Paul Morris, Naoko Shimazu and, Edward Vickers (eds), Imagining Japan in Post-war East Asia, op. cit., Chapter 4.

25. Shen Qiwei et al., Lishi (History), Shanghai jiaoyu chubanshe (Shanghai Educational Press), 1995, in two volumes (for Senior High School, Grade One).

26. Caroline Rose, "Changing Views of the Anti-Japanese War in Chinese High School History Textbooks," art. cit.

27. Ibid., p. 144

28. Ibid., p. 145

29. Shen Qiwei et al., Lishi (History), 1995, Vol. 1, pp. 109-110. A separate section on CCP-led guerrilla activities emphasises the inspirational role of Mao.

30. Ibid., p. 111

31. Ibid., p. 123

32. See Edward Vickers, In Search of an Identity, op. cit. 
in Western Europe," and the modern history of East Asia is presented as a series of national responses to the Western "impact." Capitalism is portrayed as a necessary stage of historical development, wisely embraced after "American cannons opened Japan's closed door" (meiguo da pao dakai riben suoguo damen). The Meiji elites' realistic understanding of the fruitlessness of blind rejection of the outside world (mangmu paiwai) earned them the "encouragement and support of the masses" (renmin qunzhong de tuidong he zhichi). ${ }^{(33)}$ This is contrasted with the "official corruption and economic weakness" blamed for China's failed self-strengthening efforts and defeat at the hands of Japan in 1894-1895. (34) Like China, Japan was coerced into signing "unequal treaties," but institutional reform and economic modernisation enabled it to avoid subjugation. "The Meiji Restoration put Japan on the road to capitalist development, [paving the way for the] later gradual abolition of the unequal treaties, thus escaping (baituo) a national crisis (minzu weiji), and becoming a strong Asian nation (yazhou qiangguo)." (35) While thus praising Meiji-era nation building, the 1995 text also criticises its class-based character. The extreme emphasis of the education system on "loyalty and patriotism" (zhongjun aiguo) is blamed for "poisoning the thinking of citizens." The incompleteness of capitalist reform, and the retention by "feudal remnants" (fengjian canyu) of ultimate political authority are blamed for making Japan a "militarist feudal imperialist country (junshi fengjian tiguozhuyi guojia) with a large tendency for invading [other countries]." (36) Japan's wars with China (1894-1895) and Russia (1904-1905) are identified as marking a transition from "capitalist" to "imperialist" development, and the text highlights the reparations levied on the defeated Qing government after 1895, and the investment of the majority of this "huge sum" in further military development. (37) Japan's acquisition after 1905 of Russia's privileges in Manchuria, notably the Southern Manchuria Railway, is described as an initial stage in the "invasion" of North-east China. ${ }^{(38)}$

This invasion, the ultimate consequence of perverted capitalist development, leads to disastrous defeat and the kind of subjection to Western domination Japan had avoided during the Meiji period. Through the occupation reforms, America "strengthened its influence and control over Japan," while failing to purge "remnants of militarism" (junguo zhuyi canyu). ${ }^{(39)}$ The onset of the Cold War and the Korean conflict rendered Japan a useful anti-Communist base, prompting the Americans to encourage rearmament and allow the formation of many "right-wing groups." 1952 marked the end of the "open occupation" and recovery of "formal independence," but Japan remained in a state of "semi-occupation" (ban zhanling zhuangtai). However, the subsequent strengthening of its economy led to increasing autonomy (zi zhu) and a more equal relationship with America. (40) By the 1980s, Japan was an "economic great power" (jingii da guo), and many Japanese politicians began more openly to call for political influence to match their country's economic clout. Once again, the importance of economic strength to resisting Western hegemony is emphasised.

While identifying the West (later joined by Japan) as "oppressing" and the non-West as "oppressed," the blame for this is largely attributed to the contradictions of global capitalism. ${ }^{(41)}$ Moreover, these are traced within as well as between countries. Analysis of "The origins of war in Asia and Europe" ( $Y a, O u$ zhanzheng ceyuandi de xingcheng) appears in a chapter focusing on the Wall Street Crash, the Great Depression and their consequences. An examination of how "Japan became the source of war in Asia" (riben chengwei yazhou zhanzheng ceyuandi) stresses the relationship between economic crisis, growing militarism, and "fascistic" tendencies. Japan's escalating incursions into China during the 1930s are thus discussed against this background of domestic turmoil. The text asserts that "the Japanese people did not want war. But all kinds of anti-war elements in Japan at that time were relatively weak and unable to coordinate themselves effectively." It describes how State Shinto and the evocation of the emperor's divine status were used to whip up fanatical support for a "sacred war" (sheng zhan), leading Japan down a "criminal and dangerous path" (zui e er weixian de daolu). ${ }^{(42)}$ The characterisation of Japanese politics as "fascist," and the juxtaposition of this discussion with an account of the rise of Hitler, underlines the role of broader global currents.

The 1995 narrative thus adheres to Marxist orthodoxy in portraying nations largely as pawns in an international drama driven by impersonal forces - class struggle, capitalism, imperialism. The internationalist slant of the account extends to acknowledgement of Japan's role in inspiring and harbouring some of the key figures in China's early-twentieth-century reformist and revolutionary movements, including Sun Yatsen. ${ }^{(43)}$ However, historical materialist teleology ultimately fails to deliver a revolutionary telos. After briefly mentioning the collapse of European Communism, the break-up of the Soviet Union, the wars in Iraq and Yugoslavia, and America's new status as sole global "hegemon," the text concludes by calling for "peoples of every nation" to address themselves to two overriding challenges: the pursuit of "peace" and of "development." This was neutered post-Cold War socialism, shorn of revolutionary intent, but retaining faith in progress and modernisation, albeit alongside lingering suspicion of Western "hegemonism." But more than any explicit ideology, the integration of national and global history throughout the text delivered a vision of an interconnected world suited to a city whose role, as Deng Xiaoping re-launched his reforms, was to declare China open for international business.

\section{The 2004 series $^{(44)}$}

The late 1990s and early 2000s witnessed much debate in Chinese educational circles over "quality education" (suzhi jiaoyu), echoing concerns expressed by educators elsewhere in East Asia. Advocates of curricular reform pointed to an excessive pedagogical focus on factual recall, crushing intellectual curiosity and individual initiative - qualities seen as essential for success in the "knowledge economy." At the head of those calling for "quality'-oriented reforms was the prominent Shanghai-based educator,

33. Edward Vickers, In Search of an Identity, op. cit., p. 154.

34. Ibid., p. 199

35. Ibid., p. 154

36. Ibid., p. 155

37. Ibid., p. 185. The text also notes the role of industrial and commercial concerns in Japan's colonial enterprise - for example, in the development of Taiwan's sugar plantations and the establishment of textile factories in Shanghai.

38. Ibid., p. 186.

39. Shen Qiwei et al., Lishi (History), 1995, Vol. 2, 1995, p. 167.

40. Signified by the new security treaty of 1960 and the withdrawal of residual American powers to interfere in Japanese affairs.

41. Echoing Lenin, Chapter 16 is entitled "Capitalism entering the stage of Imperialism."

42. Ibid., p. 79. A section on "national liberation struggles in Korea and India" records how Shanghai served as the base of the Korean Government in Exile during 1930s (p. 87). The insertion of this reference was a consequence of China's warming relations with the Republic of Korea after the normalisation of bilateral relations in 1992. Since then, it has become traditional for every newlyelected ROK President to visit the site of the former headquarters of the Korean Provisional Government in Shanghai.

43. Ibid., Chapter 18, especially pp. 220-221.

44. Su Zhiliang et al., Lishi (History), two volumes, Shanghai Educational Press (Shanghai jiaoyu chubanshe), 2004. (Experimental versions were used in local schools from 2003). 
Zhong Qiquan, an expert on Japan. Zhong was influenced by Japanese debates over the introduction of yutori kyouiku ("relaxed" education) and curricular integration. ${ }^{(45)}$ He was one of the main movers behind the 2001-2 reforms to the national school curriculum. These extended the autonomy enjoyed by Shanghai to other provinces and municipalities, introducing the principle of "one syllabus, many textbooks." Rather than specifying the curriculum in minute detail, syllabuses would henceforth stipulate subject aims and the broader parameters of content, allowing for greater diversity in teaching materials. Textbooks nonetheless remained subject to official vetting and approval.

History - long associated in the minds of progressive educators with the dead hand of ideology - was not accorded a high priority in the revised high school curriculum; timetable space was yielded to other, ostensibly more useful subjects (such as English). Although, at junior high level, a conventional chronological approach was retained, the new senior high curriculum reflected a different conception of the nature and purpose of history as a school subject. In the 2004 Shanghai texts in particular, the integration of national and global history was taken to a new level. The previous focus on high politics was also abandoned in favour of cross-cultural comparison of habits, customs, and institutions, as reflected in the titles of the six "themes" around which the course was organised:

1. Early Human Civilisation (renlei zaoqi wenming)

2. Human Life (renlei shenghuo)

3. Human Culture (renlei wenhua)

4. Civilisational Blending and Conflict (wenming jiaorong yu chongtu)

5. Civilisation in the Age of Economic Globalisation (zou xiang jingji quanqiuhua shidai de wenming)

6. The Current State of Civilisation and its Future (wenming de xianshi he weilai)

The framing of the Chinese and global past as a story of transitions through phases dictated by historical materialism was thus superseded by a focus on "civilisation" and, by implication, "progress."

Zhou Chunsheng, one of the principal authors of the series, identified Fernand Braudel's "total history" as a key inspiration, declaring that history belonged not to "emperors or generals," but to "the people." (46) Zhou claimed that this model of history education had already won broad acceptance in Europe and America, implying that where the West had led, China should follow. If the influence of Braudel permeates the series, so, arguably, does that of Toynbee, with his interest in the rise and fall of civilisations, largely categorised according to religion. This focus is reflected in the way in which the texts draw examples from ancient Egypt and Mesopotamia; India; ancient Greece and Rome; medieval and modern Europe; America; and China itself - above all from the last three.

The unstated assumption that an East Asian "Sinosphere" constitutes one of these self-contained civilisations had implications for the coverage of Japan and Korea, which the authors appeared to regard as insufficiently distinct from China to warrant much separate attention. ${ }^{(47)}$ This somewhat gives the lie to the vaunted cosmopolitanism of their approach, since the assumption that "Chinese" civilisation encompasses the whole of East Asia is a classic expression of Han chauvinism. Indeed, emphasising the status of the People's Republic of China as trustee of the world's only "ancient civilisation" with an "unbroken history" of thousands of years was recommended as a theme of patriotic education as long ago as 1951.(48)
However, the spotlight in these texts falls largely on Europe and, especially in sections on the contemporary period, on America. In general, coverage of the West is far more positive than in earlier texts. A chapter on human rights, for example, traces the origins of Western rights discourse (through Rousseau and the French Revolution), cites the Holocaust as background to the Universal Declaration of Human Rights, and notes the influence of this on contemporary Chinese political thought. It largely eschews the attacks on Western hypocrisy that are a standard feature of discussions of "rights" in Chinese texts. ${ }^{(49)}$ Commenting approvingly on the new texts, Gerard Postiglione, an American expert on China's education system, explained that "the emphasis is on producing innovative thinking and preparing students for a global discourse." It was "natural," he went on, for local curriculum developers to question whether the conventional textbook narrative of modern Chinese history, that "talks so much about Chinese suffering during the colonial era," was suited to "creating the kind of sophisticated talent they want for today's Shanghai." (50)

The New York Times (NYT) journalist interviewing Postiglione observed that junior high texts continued to use "boilerplate idioms to condemn Japan's invasion of China in the 1930s" and included "little about Tokyo's peaceful, democratic post-war development," thus doing "little to assuage Japanese concerns that Chinese imbibe hatred of Japan from a young age." The main two-volume text indeed pays scant attention to Japan's post-war history: there is a picture of a shinkansen, passing reference to Japanese involvement in the International Space Station, and an account of the Aum Shinrikyou subway attack in the context of a chapter about "cults" (xiejiao). ${ }^{(51)}$ However, neither do these volumes feature laboured condemnations of Japan's invasion of China; in fact, reference to the war and attendant atrocities is almost entirely absent.

An account of Japan's post-war development was nonetheless included in the Year 3 senior high textbook studied only by students in the "humanities" stream. ${ }^{(52)}$ As well as a two-page, conventional account of the War of Resistance - relatively light on "boilerplate idioms" - there is a chapter on Japan's "modernisation," the last of six dealing with "The Process of Modernisation in Major Developed Countries." This begins with a rather glowing account of the Meiji era, emphasising the merits of the Westernised educa-

45. For an exposition of Zhong's educational philosophy, see Zhong Qiquan and You Baohua, "Fahui de nailao: Renzhen duidai qingshi zhishi de jiaoyu sichao duhou gan" (Rotten cheese: Feelings after reading "A Critical Reflection on the Thought of "Despising Knowledge" in Chinese Basic Education), in Quanqiu Jiaoyu Zhanwang (Clobal Education), Vol. 33, No. 10, 2004, pp. 3-7.

46. Quoted by Joseph Kahn, "Where's Mao? Chinese revise history books," The New York Times, 1 September 2006.

47. One of very few references to Japanese culture comes in a discussion of "coming-of-age ceremonies." This refers to the ancient Chinese festival (cheng ren jie) celebrated by those who have reached the age of twenty - but the accompanying picture shows contemporary Japanese youths, in traditional costume, celebrating the equivalent festival (sei-ren jitsu). For students already aware of the regional influence of Chinese "civilisation," the implication is clear: this festival is just one instance of Japan's extensive cultural borrowings from pre-modern China. Su et al., 2004, Vol. 1, p. 78

48. Hsu T'e-li et al., On the Education of Patriotism, Peking Mass Bookstore, 1951, cited in C. T. Hu, "Orthodoxy over Historicity:The teaching of history in communist China," Comparative Education Review, 1969, Vol. 13, No.1, pp. 2-19.

49. See Edward Vickers, "Selling Socialism with Chinese Characteristics: Thought and Politics and the legitimisation of China's developmental strategy," in the International Journal of Educational Development, Vol. 29, 2009, pp. 523-531. In the 2004 Shanghai texts, a discussion of Rosa Parks (Book 2, p. 98) alludes to America's racial problems - a longstanding theme of Chinese textbooks - but rather than highlighting continuing racial divisions underlines Parks's role in bringing about progress on this issue.

50. Quoted in Joseph Kahn, "Where's Mao? Chinese revise history books," art. cit.

51. Su Zhiliang et al., Lishi (History), op. cit., Lesson 25.

52. Su Zhiliang (chief editor), History for Senior Secondary Year Three (Experimental Edition) (Lishi: Gaozhong san nianji [shiyan ben]). Shanghai, Shanghai Educational Press, 2005. Su reflects on Chinese textbook representations of Japan in Su Zhiliang et al., Lishi (History), 2011, op. cit. 
tion system introduced during this period. ${ }^{(53)}$ As in the 1995 text, the subsequent descent into war and overseas expansion, from the 1890 s onwards, is represented as the tragic consequence of a deviation from the early Meiji ideals (and from the "objective laws" of history). ${ }^{(54)}$ Democratisation and the success of Japan's postwar "economic miracle" (jingji qiyi) are highlighted in the postwar section. However, students are also reminded of Japan's failure (by comparison with Germany) to confront issues of "war guilt," the Japanese government's approval of a right-wing history textbook, ${ }^{(55)}$ and the continued honouring of convicted war criminals in Tokyo's Yasukuni Shrine. Again, this largely reproduces material from the 1995 text, which had reminded students that "for many years, elements within the Japanese elite have made statements denying the criminal invasion [of China and other Asian countries] - something that has not failed to attract the notice of China and other countries that suffered deeply at the hands of Japanese militarism." (56)

Ironically, the largely approving NYT article seems to have triggered the hurried withdrawal of the 2004 texts. Its headline asked "Where's Mao?", the answer being: almost nowhere. The new texts had already come under criticism from more conservative scholars, who claimed that they trivialised history. In addition, the broader attempt to introduce "integrated" approaches and other pedagogical reforms across the school curriculum was meeting with significant resistance from teachers, many of whom found the innovations incomprehensible and misaligned with the requirements of public examinations. ${ }^{(57)}$ Shanghai's history textbooks went even further than those used elsewhere, which, although divided into "economics," "politics," and "culture" volumes, maintained a conventional chronological approach. In this context of pre-existing controversy over the wisdom or practicability of the post-2001 curricular changes, ${ }^{(58)}$ the political storm caused by the NYT article appears to have sealed the fate of the Shanghai series. ${ }^{(59)}$ Six weeks after the article's publication, the Senior High School Social Studies Research Centre of the Central Government's Education Ministry issued a report authored by a group of "famous" Beijing-based historians criticising Shanghai's senior high history textbooks. They objected to the "incoherent" (hunluan) thinking of the texts' authors, their neglect of "the realities of contemporary China's social development," their "anti-ideological" (fei yishi xingtai) stance, and their effective abandonment of Marxist historical materialism. ${ }^{\left({ }^{60}\right)}$ After fruitless attempts by the chief editor, Su Zhiliang, to negotiate a revision to the series, the Educational Committee of Shanghai Municipality peremptorily announced, in mid-May 2007, that the books would be withdrawn and replaced as of 1 September. ${ }^{(61)}$

The 2004 Shanghai texts represented a radical attempt to extend the integration of national and global history pioneered in the preceding 1995 edition. Indeed, so far did this integration proceed in the two-volume compulsory course that the nation almost dissolved away in a solvent of "civilisation" and broadly-conceived "progress." But if the nation faded from view, then on what hook could messages of "patriotic education" be hung? The answer is partly to be found elsewhere in the school curriculum, where subjects such as Thought and Politics and (Chinese) Language and Literature continued to offer ideologically more conventional fare. However, that the logic of their historical vision led the authors of this series away from themes readily susceptible to "patriotic" treatment is perhaps not accidental. Su Zhiliang's own testimony suggests that "patriotic education" was not his foremost concern when it came to the portrayal of Japan; instead, he emphasised the aim, central to the suzhi jiaoyu movement and the 2002 curriculum reforms, of stimulating students to analyse and reflect. ${ }^{(62)}$ In practice, much of what coverage of Japan there was - in the compulsory course, and especially in the separate volume for third-year students - still alluded to familiar negative stereotypes. However, the authors appear to have been keen not to scratch the sore points in China's external relationships, of which those involving Japan were among the sorest. Their text is suffused by a vision of the international order that is essentially harmonious, progressive, and optimistic. Whether the failure to reference Mao was intentional or Freudian, it was undoubtedly a product of the absence from this vision of recognisably socialist concepts. And this in turn reflected the fact that socialism, especially of the Maoist brand, had come to seem a particularly remote and alien creed in twenty-first-century Shanghai.

\section{The 2007 series $^{(63)}$}

The short time allowed for the drafting of texts (by new authors and a new publisher) to replace the withdrawn 2004 edition prompted the adoption of a modular approach, with volumes produced term-by-term rather than all at once. Both the rushed nature of the enterprise and the political context in which it was undertaken help account for the reversion to triedand-tested formulae, pedagogical as well as ideological. The narrative structure of the 1995 series has been largely reinstated, along with much Marxist terminology; historical materialism and "modes of production" are often invoked, for example in the titles of sections on "the shoots of capitalist relations of production" (in fifteenth-sixteenth-century Europe) and "the formation of the capitalist world system" in the mid-nineteenth century (when it is noted that Japan joined the ranks of the "capitalist" states). Although national and global history are still discussed within the same set of covers, the new series is rather less integrated than its 1995 predecessor.

53. Su Zhiliang, History for Senior Secondary Year Three, op. cit., p. 141

54. Ibid., p. 151.

55. In common with most Chinese reports on this issue, it is not explained that the right-wing book is one of a number of approved texts, and is used only in a tiny minority of Japanese schools.

56. Ibid., p. 168. Although, in the chapter on the war itself (p. 111), the 1995 text also notes that, since the establishment of the Nanjing Massacre Memorial, many "upright Japanese public figures" (zhengzhi de riben renshi) have visited [...] and sincerely expressed their feelings of guilt and remorse (fujiu de xinqing).

57. John Chi-Kin Lee, Hong-biao Yin, Zhong-hua Zhang, Yu-le Jin, "Teacher Empowerment and Receptivity in Curriculum Reform in China," Chinese Education and Society, 2011, Vol. 44, No. 4, pp. 6481. Lee et al. found that the reforms were insufficiently backed up by effective in-service teacher training, with trainers themselves often "seriously confused" about the theories underlying the new curriculum.

58. Zhong Qiquan and You Baohua, "Fahui de nailao," art. cit., is part of a heated exchange between advocates and critics of the reforms in the pages of the journal Global Education.

59. The sensitivity surrounding this issue, and absence or inaccessibility of relevant official documentation, render it hard to produce a "smoking gun" linking the withdrawal of the 2004 series directly to the NYT article. Nonetheless, those in a position to know informally confirm this interpretation of events.

60. The report, published on 16 October 2006, was entitled "Famous historians criticise Shanghai's new senior high history textbooks" (Chuming lishi xuejia ping Shanghai xinban gaozhong lishi jiaokeshu). See "Short-lived and rushed Shanghai history textbooks" (Duanmingde yu suchengde huban lishi jiaocai), in China Review News, 18 September 2007, published online: www.china reviewnews.com/doc/1004/5/1/9/100451914_2.html (accessed on 11 April 2013).

61. The tone of one anonymous commentator was typical: he accused the authors and their supporters of "neoliberalism" and of attempting to "dilute ideology" and "dilute the history of struggle" (douzheng lishi), while attacking the (relatively liberal) newspaper Southern Weekend (Nanfang Zhoumo) for its criticism of the rushed production of the replacement series. See "Necessary reaction: On the withdrawal from use of Shanghai's textbooks on 'The History of Civilisation"' (Biyaode fanji: kan Shanghai tingyong "wenmingshi" lishi jiaokeshu), http://big5.china.com/ gate/big5/club.china.com/data/thread/4411577/114/34/52/7_1.html posted on 14 September 2007 (accessed on 11 April 2013).

62. See Su Zhiliang et al., Lishi (History), 2011, op. cit.

63. Xu Wei Min et al., Gao zhong lishi, Shiyan ben (High School History [Experimental edition]), Huadong shifan daxue chubanshe, in six volumes (2007-2009). 
Chinese history is generally dealt with in distinct chapters rather than within more broadly-themed units.

The overall approach is no more conventionally Marxist than that of the 1995 books. However, China's "revolutionary" movements (such as the Taiping Rebellion of the mid-nineteenth century) are celebrated, and more prominence is given to revolutionary leaders such as Sun Yatsen and, unsurprisingly, Mao Zedong. The Communist Party's contributions to China's development are emphasised, with extended treatment of the country's post-1949 history. The new texts contain more allusions to local history than previous series, using local examples to embellish accounts of national events: for example, the chapter on the Cultural Revolution (blamed squarely on the Gang of Four) pictures the establishment of the "Shanghai Revolutionary Committee." (64) The text for year three of senior high school also features a new, dedicated local history section - but at this stage the subject is only studied by arts and humanities students.

That the current texts are less thoroughly integrated, or internationally comparative, than their 1990s predecessors is partly a consequence of their less consistent reliance on a Marxist interpretative framework. Although the Meiji Restoration and China's self-strengthening movement are discussed in terms broadly similar to those found in earlier texts, students are not similarly invited to compare the Chinese and Japanese experiences of modernisation. ${ }^{(65)}$ The fact that Sun Yatsen visited Japan, and even founded the Tongmenghui there, is afforded the briefest of mentions, but the role of Japanese precedents in influencing the thought of major Chinese reformers and revolutionaries is not explicitly noted or discussed. ${ }^{(66)}$ Although the differences of detail are individually trivial, in sum they enhance the emphasis on Chinese agency in general, and that of "great men" in particular, in the grand quest for modernisation and national strength - and diminish any acknowledgement of Japan's contribution thereto. And when it comes to war and invasion, class struggle is no longer allowed to exculpate the Japanese masses: students are told that "Japanese fascism first arose from within civil society" (shouxian chanshengyu minjian). (67) The War of Resistance receives extended coverage, with the escalating conflict represented primarily as a consequence of "national contradictions" between Japan and China (zhong ri liang guo jian de minzu maodun). ${ }^{(68)}$ New illustrations embellish descriptions of Japanese atrocities, ${ }^{(69)}$ and the total number of victims of the Nanjing Massacre is cited as "more than 300,000." (70) Contrasted with the callous brutality of the invaders is the steadfast virtue of the Chinese: an account of the Communist-led "One Hundred Regiments Offensive" of 1940 features a new story about the rescue of stranded Japanese children. (71) Merciful Chinese are contrasted with merciless Japanese.

This new series thus reinstates a conventional chronological approach, a further-diluted variant of the Marxism of the 1995 texts, and a heightened emphasis on Japanese iniquity. Meanwhile, nationally, the more thematic approach to senior high school history mandated by the curriculum reforms of 2001-2002 remains in place - but for how much longer? The "Where is Mao?" debacle meant that the conservative backlash against "integrated" history teaching was unleashed early in Shanghai - but it is a phenomenon that extends well beyond the municipal boundaries. If the 2004 texts put Shanghai at the forefront of a national move away from Marxist teleology and towards a radically thematic, integrated, and cosmopolitan vision of history education at senior high level, then it is also quite possible that the city may now be leading the way back towards an ideologically and pedagogically far less adventurous approach.

\section{Conclusion}

This article has traced the shifting depiction of Japan through three editions of Shanghai's senior high history textbooks. In the 1990s, the history of modern Japan and its relations with China received extensive coverage, but Marxist internationalism and class-based analysis moderated "antiJapanese" messages. While criticisms were levelled at aspects of Japan's political system and specific policies, these were primarily attributed not to an essentially malign national character, but to historical contingency and elite machinations. This interpretation - consistent with China's position since diplomatic normalisation in the 1970s - left the Japanese people themselves largely off the hook for the "crimes" of their country's modern history.

Between the publication of the earliest series and that of its successor in 2004, China witnessed an ambitious overhaul of the formal school curriculum in 2001-2. Among the chief advocates of these reforms was Zhong Qiquan of Shanghai's East China Normal University, who in turn derived many of his ideas from contemporary Japan (or from the West via Japan). The subsequent revision of the senior high history curriculum epitomised key ideas underlying these reforms. Rather than recapitulating the junior secondary curriculum, the new texts offered a radically different "integrated" global history. Abandoning the traditional focus on nations - though evincing a naive faith in Western modernity and progress - the two-volume compulsory course presented a "civilisational" perspective on the past. This left little space for depiction of Japan, negative or otherwise.

However, this 2004 series ultimately tested to breaking point the limits of Shanghai's curricular autonomy. Following the publication of the New York Times article "Where is Mao?" in September 2006, an official backlash led to the hasty withdrawal of these texts the following spring. The new series placed the nation once again centre stage, while a heightened focus on Chinese history and largely tokenistic deployment of Marxist terminology lent the narrative a significantly more nationalistic tone. Neglecting to distinguish between malign elites and downtrodden masses, or to highlight the role of international forces, the narrative endows national collectivities such as "China" and "Japan" with essential characteristics and intent. Japan's influence on China's modernisation is ignored in favour of an account that highlights the role of visionary leaders, especially Sun Yatsen, Mao Zedong, and Deng Xiaoping. Tropes of Japanese brutality, Chinese humanity, and the triumphant transcendence of victimhood, common to junior and senior high

64. Xu Wei Min et al., Gao zhong lishi, op. cit., Vol. 6, p. 99

65. Xu Wei Min et al., Gao zhong lishi, op. cit., Vol. 4, pp. 75-78.

66. The Year 3 volume features a unit on "the development of Chinese historiography," with discussion of Liang Qichao's essay "On the New History" (p. 103). This ignores Japan's contribution to the development of Liang's thought. And in coverage of Deng Xiaoping's modernisation drive, no mention is made of Deng's admiring references to Meiji Japan - let alone to the contemporary role of Japanese aid, investment, and technology.

67. Xu Wei Min et al., Gao zhong lishi, op. cit., Vol. 5, 2008, p. 132

68. Xu Wei Min et al., Gao zhong lishi, op. cit., Vol. 6, 2008, p. 2.

69. The series of 2004 and 2007 feature far more illustrations than that of 1995 , with colour reproductions and photographs replacing the earlier line drawings. This reflects advances in publishing technology, rising textbook prices, and a concern to make texts more appealing and stimulating.

70. Xu Wei Min et al., Gao zhong lishi, Vol. 6, op. cit., p. 5. The same rise in the official victim count is evident elsewhere; the 300,000 figure has become sacrosanct.

71. Ibid., p. 10 
texts elsewhere on the mainland (and to museum displays - see Vickers' article in the current issue of China Perspectives), resume their place in a thoroughly orthodox account of the recent national past.

Shanghai's license to experiment in history curriculum development thus appears to have been effectively revoked, but in truth it was never very extensive. Given the strong municipal pride and sense of local identity - evident, for example, in the city's museums - it is noticeable that the local senior high textbooks have never featured much coverage of local history. Autonomy has meant mandating textbook editors to present the standard, approved narrative of the national and global past in a manner suited to local educational conditions.

In Hong Kong, by contrast, a substantial proportion of the history curriculum has been devoted to local history. However, a look at how Japan has been portrayed in the national (Chinese) and world history sections of Hong Kong's recent school textbooks reveals a tone no less strident, and arguably more so, than the latest Shanghai texts. Meanwhile, in their coverage of local history, textbooks typically play down the extent of Hong Kong's distinctiveness from the mainland, highlighting instead China's "contributions" to the region's development. ${ }^{(72)}$ There is little acknowledgement of Japan's role as Hong Kong's main trading partner for much of the post-war period, and no discussion of the huge influence of Japanese popular culture on the local media and fashion scene.

This serves to remind us that what is left out of a historical narrative is at least as important as what is left in. ${ }^{(73)}$ As regards the depiction of modern Japan in the textbooks of Shanghai or Hong Kong, this "null curriculum" relates especially to Japan's contribution to China's modernisation, both in the early twentieth century and since the advent of the "Reform and Opening" period in the late 1970s. Also ignored or (at best) downplayed is the wartime suffering of the civilian Japanese population, appreciation of which is essential to any understanding of postwar Japan's strong commitment to peace. At the same time, what is said about Japan needs to be seen in the light of what is not said about China. For obvious reasons, it is far easier for textbook editors to heap blame on Japan for early-twentieth-century atrocities than it is to discuss more recent sufferings inflicted by Chinese on Chinese. For example, the Great Leap Forward and Cultural Revolution receive scant coverage, the scale of casualties is played down, and blame is vaguely apportioned. Such events are portrayed as unfortunate setbacks in the otherwise triumphant march of national improvement under Communist rule, leaving the Japanese invasion to stand as the supreme catastrophe of China's modern history.

These are not original criticisms; indeed, they are frequently voiced in Japanese responses to Chinese attacks on Japan's history textbooks. Japan's media typically represents Chinese hostility as something manufactured by regime propaganda, not least through the vehicle of schooling. ${ }^{(74)}$ There is much truth in this, but the question too seldom asked - particularly in Japan - is "Why does this propaganda resonate with so much of the Chinese public?" In Hong Kong, still beyond the direct reach of the Communist Party's propaganda apparatus, many of those most active in Diaoyu/Senkaku protests have also been at the forefront of local criticism of Beijing's role in local affairs. ${ }^{(75)}$ The demographics of protest on the mainland are murkier - but there, too, considerable overlap may exist between constituencies for anti-Japan protest and for domestic dissent. ${ }^{(76)}$ While the latter incurs obvious risks, venting at Japan is both less controversial and more difficult to suppress. Consensus over Japan's wartime record also explains why Hong Kong texts especially have tended to gild the patriotic lily in portrayals of Japan - even while attempts to introduce an overtly pro-Beijing programme of "Moral and National Education" (MNE) have met with fierce local resistance. ${ }^{(77)}$ Political and commercial pressure from the mainland play their part, but so does the fundamentally uncontroversial nature of anti-Japan messages.

As in Hong Kong, so in Shanghai, attempts at a pedagogical "revolution from above" have thus recently foundered - but the political dynamics have been very different. In Hong Kong, a Beijing-sponsored initiative met with concerted local opposition made possible by constitutionally-enshrined civic freedoms. In Shanghai, the central government conferred on local officials powers that were used to introduce, with minimal consultation, a radical (and ironically liberal) new approach to history education; but when the resulting textbooks caused political embarrassment, the authorities in Beijing could swiftly intervene to ensure their withdrawal. The fact that local texts then reverted to a more nationalistic narrative, with conflict with Japan a major theme, illustrates how in Shanghai as elsewhere in China, peddling such messages represents the safest option for those eager to avoid official reprimand or popular criticism. As the latest editions of Shanghai's textbooks demonstrate, this does not necessarily imply strident xenophobia; indeed, the anti-Japan slant of these texts may seem moderate by comparison with that of their counterparts in some of the more open and democratic societies of East Asia. ${ }^{(78)}$ Shanghai's texts, like Chinese textbooks generally, are also far more restrained in their treatment of Japan than the popular media and the nationalist blogosphere. However, nationalism - in China as elsewhere - renders balanced or nuanced coverage of sensitive issues politically difficult. Thus, while Sino-Japanese conflict remains central to the orthodox account of national history, discussing Japanese influence on the cultural, economic, and institutional development of modern China remains far more problematic, even in the city that in many ways epitomises that legacy.

\section{Edward Vickers is Associate Professor in Comparative education at the Department of education of Kyushu University. \\ Kyushu University, 6-19-1 Hakozaki, Higashi-ku, Fukuoka 812-8581, Japan (vickers.edward.645@m.kyushu-u.ac.jp).}

\section{Yang Biao is Associate Professor of history at East China Normal University, Shanghai, China. His current research and teaching interests include world history, history education, and history reconciliation in East Asia. \\ Department of History, East China Normal University, Shanghai, China (ybiao122@hotmail.com).}

72. See the article by Christine Han in the current issue of China Perspectives.

73. A point emphasised by Gi-Wook Shin and Daniel C. Sneider (ed), History Textbooks and the Wars in Asia: Divided Memories, Routledge, 2011.

74. See, for example, the lead article in the September 2013 issue of the magazine Bungei Shunju, "Prepare for a Hundred Years War with China and Korea," pp. 94-112.

75. The prominent Democratic Party legislator Cheung Man-kwong is a prime example.

76. A September 2012 report by Agence France-Presse cites Zhang Min, a political scientist at Beijing's Renmin University, remarking how "some protesters in recent anti-Japan demonstrations over a disputed island chain carried banners that voiced support for Bo [Xilai]." www.rappler.com/ world/13322-china-targets-dissent-in-attack-on-bo-analysts, (accessed on 16 September 2013).

77. See Sebastian Veg, "Hong Kong's Enduring Identity Crisis," The Atlantic (online), 13 October 2013. www.theatlantic.com/china/archive/2013/10/hong-kongs-enduring-identity-crisis/280622/ (accessed on 13 October 2013).

78. Hong Kong being one more "open" - though not democratic - example; South Korea being another. On Korea, see Gi-Wook Shin and Daniel C. Sneider (ed), History Textbooks and the Wars in Asia, op. cit., especially Chapters 4, 5, and 7 . 